\title{
Minat, Perilaku Belajar Mahasiswa dan Tingkat Pemahaman Akuntansi Pengantar Berdasarkan Latar Belakang Pendidikan
}

\author{
Sri Ayu Wulandari ${ }^{1}$ \\ Fakultas Ekonomi dan Bisnis \\ Universitas Udayana, Indonesia
}

\author{
Luh Gede Krisna Dewi ${ }^{2}$ \\ Fakultas Ekonomi dan Bisnis \\ Universitas Udayana, Indonesia
}

\begin{abstract}
Surel: wulanayu448@gmail.com
ABSTRAK

Tingkat pemahaman akuntansi pengantar merupakan fondasi yang sangat memengaruhi pemilihan bidang pekerjaan kedepan. Beberapa lulusan akuntansi yang sudah bekerja namun tidak sesuai bidangnya. Hal tersebut dapat disebabkan kurangnya minat dan buruknya perilaku belajar selama menjalani pendidikan. Penelitian ini bertujuan menganalisis pengaruh minat dan perilaku belajar mahasiswa pada tingkat pemahaman akuntansi pengantar. Penelitian ini dilakukan di FEB Unud pada mahasiswa S1 Akuntansi angkatan 2018, dengan metode purposive sampling, sebanyak 200 responden. Pengumpulan data melalui penyebaran kuesioner. Teknik analisis data yang digunakan adalah analisis regresi linier berganda. Hasil penelitian menunjukkan bahwa minat dan perilaku belajar berpengaruh positif dan signifikan pada tingkat pemahaman akuntansi pengantar. Semakin tinggi atau baik minat dan perilaku belajar maka semakin tinggi pula tingkat pemahaman akuntansi pengantarnya.
\end{abstract}

Kata Kunci: Minat; Perilaku; Pemahaman Akuntansi Pengantar.

\section{Interests, Student Learning Behavior and Level of Understanding of Introductory Accounting Based on Educational Background}

\begin{abstract}
The level of understanding of accounting principles is the foundation that greatly influences the choice of occupations of future employment. Some accounting graduates who have worked but not in their fields. This can be caused by lack of interest and poor learning behavior while undergoing education. This study aims to analyze the influence of students' interest and learning behavior on the level of understanding of accounting principles. This research was conducted at FEB Unud on S1 Accounting students in class 2018, with a purposive sampling method, totaling 200 respondents. Data collection through questionnaires. The data analysis technique used is multiple linear regression analysis. The results showed that interest and learning behavior had a positive and significant effect on the level of accountingprinciples understanding. The higher or better the interest and learning behavior, the higher the level of understanding of the accounting principles.
\end{abstract}

$\begin{array}{ll}\text { Keywords: Interests; Behavior; Accounting Principles } \\ & \text { Understanding. }\end{array}$

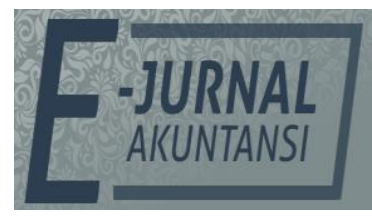

e-ISSN 2302-8556

Vol. 31 No. 1

Denpasar, Januari 2021

Hal. 92-105

DOI:

10.24843/EJA.2021.v31.i01.p07

PENGUTIPAN:

Wulandari, S.A., \& Dewi,

L.G.K. (2021). Minat,

Perilaku Belajar Mahasiswa dan Tingkat Pemahaman

Akuntansi Pengantar

Berdasarkan Latar Belakang

Pendidikan. E-Jurnal

Akuntansi, 31(1), 92-105

RIWAYAT ARTIKEL:

Artikel Masuk:

13 Januari 2020

Artikel Diterima:

3 Maret 2020

Artikel dapat diakses : https://ojs.unud.ac.id/index.php/Akuntansi/index 


\section{PENDAHULUAN}

Pendidikan di perguruan tinggi baik itu universitas atau institut, politeknik, sekolah tinggi, dan akademi semuanya menuntut kemampuan studi yang lebih dari pada kemampuan studi yang cukup untuk menyelesaikan sekolah dasar atau menengah. Berhasil tidaknya pendidikan di perguruan tinggi diperlukan sebuah bakat studi yaitu kemampuan awal sesuai dengan bidang kompetensi yang akan di tempuh di perguruan tinggi. Dengan begitu, peserta belajar di perguruan tinggi dapat mengikuti studi tanpa terlalu bersusah payah, tidak terlampau tertekan beban, dan dapat menyelesaikan studi pada waktunya, serta dengan hasil studi optimal sesuai dengan kemampuan (Bakhri, 2011). Salah satunya pendidikan akuntansi yang dilaksanakan di perguruan tinggi ditujukan untuk mendidik mahasiswa agar sesudah ia lulus dari perguruan tinggi dapat bekerja sebagai seorang akuntan profesional yang mempunyai pengetahuan di bidang akuntansi.

Perbedaan pemahaman akuntansi di bangku kuliah dengan dunia kerja akan membuat bingung lulusan akuntansi karena kebiasaan mahasiswa yang menghafal suatu materi tetapi tidak paham tentang pelajaran tersebut. Kenyataan di lapangan ada beberapa lulusan akuntansi namun tidak bekerja di bidang akuntansi, ataupun sebaliknya. Kejadian tersebut dapat disebabkan karena kurang adanya kesesuaian kemampuan dalam diri dengan bidang yang digeluti. Sari et al. (2017) menyatakan dengan adanya tingkat pemahaman akuntansi yang baik akan melancarkan saat berada di dunia kerja yang sesuai dengan bidang akuntansi. Berdasarkan hasil survei yang dilakukan Universitas Udayana ditemukan bahwa sebesar 35,30 persen alumni Universitas Udayana yang masih tidak bekerja sesuai dengan bidang yang diambil pada saat masa perkuliahan. Hal ini dapat terjadi karena beberapa faktor, baik dari kurangnya ilmu yang dimiliki di bidangnya, kurang minat dalam bidang pekerjaannya, ataupun belum menemukan pekerjaan yang sesuai dengan bidangnya. Kesesuaian antara kemampuan awal dan jurusan yang dipilih sangatlah penting, karena dapat melancarkan dalam mengikuti perkuliahan di perguruan tinggi. Namun, banyak ditemukan mahasiswa yang menempuh studi di perguruan tinggi berasal dari latar belakang pendidikan menengah yang berbeda. Misalnya, mahasiswa program studi Akuntansi terdiri dari lulusan Sekolah Menengah Atas/Kejuruan (SMA/SMK) jurusan IPA maupun IPS. Latar belakang sekolah menengah tersebut di dalam kurikulum ada yang memberikan mata pelajaran akuntansi dan bahkan ada yang tidak ada sama sekali. Sedangkan, untuk sekolah yang memberikan mata pelajaran akuntansi pun dapat memberikan materi yang berbeda pula, sehingga pengalaman belajar akuntansi mahasiswa dari tiap sekolah dapat berbeda.

Tahun pertama di perguruan tinggi adalah masa yang sulit bagi mahasiswa karena tantangan beradaptasi dengan lingkungan belajar yang baru di samping perubahan besar dalam kehidupan mereka yang lebih luas (Kahu et al., 2017). Pada semester awal perkuliahan, akuntansi pengantar akan menjadi titik dasar mahasiswa mengenal akuntansi bagi mahasiswa yang berlatar belakang sekolah menengah yang berbeda. Para mahasiswa memiliki banyak latar belakang yang berbeda, dan setiap pertemuan kelas memiliki dinamisme unik yang harus dikenali oleh anggota fakultas dan bekerja di dalamnya (Baker 
et al., 1987). Boyd et al. (2010) menyatakan tujuan utama dari fokus konseptual di kelas akuntansi adalah untuk menghasilkan mahasiswa yang memahami dan dapat menjelaskan bagaimana peristiwa akuntansi (transaksi) mempengaruhi unsur-unsur laporan keuangan, sehingga pengetahuan akuntansi yang dimiliki mahasiswa sebagian besar dipengaruhi oleh keberhasilan pada mata kuliah ini. Accounting Education Change Commission (AECC) juga menekankan pentingnya pendidikan akuntansi pertama untuk semua jurusan bisnis dan menganjurkan bahwa pendidikan ini harus mengajarkan mahasiswa untuk belajar tentang mereka sendiri untuk memberikan pandangan yang akurat tentang profesi akuntansi kepada semua mahasiswa (Elias, 2010). Selain itu, AECC telah merekomendasikan bahwa pendidikan pengantar akuntansi memberikan mahasiswa dengan persepsi yang lebih realistik dari bidang dan keterampilan yang dibutuhkan untuk sukses (Diller-Haas, 2004).

Sebagai sebuah dasar atau fondasi, akuntansi pengatar haruslah dipahami sejak dini agar fondasi dari mahasiswa mengenai pengetahuan dasar akuntansi itu kuat. Selain itu pula akuntansi pengantar merupakan jembatan bagi mahasiswa untuk mempelajari mata kuliah akuntansi yang saling berkaitan pada semester berikutnya (Aldito, 2018). Weygandt et al. (2013: 36) menyatakan bahwa akuntansi pengantar sebagai mata kuliah pengantar dimaksudkan untuk memberikan pengetahuan mendasar mahasiswa terhadap konsep persamaan dasar akuntansi yang teridiri atas aset, liabilitias, dan ekuitas, serta mekanisme laporan keuangan.

Hasil yang diperoleh mahasiswa atas nilai akuntansi pengantar dapat mencerminkan tingkat pemahaman mahasiswa tersebut. Pada beberapa penelitian nilai " $\mathrm{A}$ " dianggap bahwa mahasiswa tersebut sudah "sangat paham" mengenai suatu mata kuliah. Hasil yang diperoleh dari nilai mata kuliah Pengantar Akuntansi I, mahasiswa yang "sangat paham" akuntansi pengantar belum mencapai 50 persen dari total mahasiswa tiap angkatan dan lebih dari 50 persen mahasiswa akuntansi masih hanya paham dan kurang paham mengenai akuntansi pengantar. Seharusnya, akuntansi pengantar sangat dipahami, karena merupakan fondasi bagi mahasiswa akuntansi untuk dapat melanjutkan ke mata kuliah akuntansi selanjutnya. Bila akuntansi dipelajari secara teori dan praktik secara terus-menerus itu adalah kunci untuk dapat memahami konsepnya (Yu, 2011). Apabila dasar akuntansi telah dikuasai dengan baik semua orang pasti akan dengan mudah menjalani dan mempraktekkannya (Syah, 2010). Jumlah waktu yang dihabiskan untuk belajar ditambah dengan praktik yang disengaja dapat meningkatkan tingkat pemahaman akuntansi (Plant et al., 2005).

Mahasiswa pada semester awal perkuliahan sudah menjadi sebuah kewajiban untuk memahami akuntansi pengantar karena akan berpengaruh pada mata kuliah akuntansi lanjutannya. Maka dengan diawali adanya sebuah minat belajar seorang mahasiswa yang besar, maka perilaku belajar yang baik akan ikut terdorong tentunya, dan dapat mempengaruhi tingkat pemahaman mahasiswa terhadap materi akuntansi pengantar yang merupakan fondasi yang wajib dipahami. Tujuan penelitian ini adalah untuk mendapatkan bukti empiris mengenai pengaruh minat dan perilaku belajar mahasiswa pada tingkat pemahaman akuntansi pengantar yang dimana akuntansi pengantar merupakan hal dasar yang harus dipahami oleh setiap mahasiswa akuntansi. 
Memahami akuntansi dengan adanya minat belajar yang tinggi adalah salah satu faktor penting yang dapat dipertimbangkan karena dapat mempengaruhi prestasi belajar. Minat adalah kecenderungan yang tetap untuk memperhatikan dan mengenang beberapa kegiatan. Kegiatan itu diminati, diperhatikan terus-menerus dengan disertai rasa senang sehingga diperoleh kepuasan. Theory of planned behavior, minat belajar merupakan salah satu variabel yang dijelaskan oleh theory of planned behavior dari hubungan pada tiap-tiap variabel lainnya didalam penelitian ini. Minat yang muncul ini disebabkan karena tiga faktor yaitu sikap dari mahasiswa yang yakin atas hasil dari perilakunya, norma/aturan yang mampu memotivasi mahasiswa, dan pengendalian yang mampu mendukung atau menghambat perilakunya dalam membuat tingkat pemahaman akuntansi pengantar seorang mahasiswa dapat menjadi lebih tinggi.

Teori atribusi menjelaskan bahwa minat belajar merupakan salah satu faktor internal dalam menentukan karakeristik seseorang, khususnya di penelitian ini tingkat pemahaman akuntansi pengantar seorang mahasiswa. Ketika mahasiswa menganggap kinerja belajar mereka relevan, mereka harus menunjukkan minat yang meningkat dalam pendidikan (Abrantes et al., 2007).

Hasil penelitian sebelumnya yang dilakukan Dian (2015) dan Atmaja et al. (2017) menunjukkan minat belajar berpengaruh secara signifikan terhadap tingkat pemahaman akuntansi dan juga penelitian menurut Sugiartini et al. (2017) dan Putra (2018) menunjukkan bahwa minat belajar berpengaruh signifikan terhadap tingkat pemahaman akuntansi. Minat dalam belajar sebagai preferensi pribadi sehubungan dengan belajar, yang kadang-kadang berarti apa yang dipilih seseorang dari satu hal daripada hal-hal lain dan kadang-kadang keadaan psikologis positif terjadi selama interaksinya dengan keadaan yang menimbulkan motif belajar lebih lanjut (Lee, et al., 2011).

Minat belajar yang tinggi akan dapat terwujud apabila mahasiswa sadar akan tanggung jawab mereka sebagai mahasiswa, sehingga mampu meningkatkan motivasi dan disiplin diri agar mampu mencapai target yang diinginkan dalam memahami suatu materi terlebih lagi akuntansi (Ishak, 2011). Minat besar pengaruhnya terhadap belajar, karena bila bahan pelajaran tidak sesuai dengan minat mahasiswa, mahasiswa tidak akan belajar dengan sebaikbaiknya, karena tidak ada daya tarik baginya. Mahasiswa akan segan untuk belajar sehingga prestasinya tidak memuaskan. Sebaliknya, jika bahan pelajaran menarik minat mahasiswa, akan lebih mudah dipelajari dan disimpan. Berdasarkan uraian tersebut, dapat dirumuskan hipotesis sebagai berikut.

$\mathrm{H}_{1}$ : Minat belajar mahasiswa berpengaruh positif pada tingkat pemahaman akuntansi pengantar.

Perilaku belajar selama berada di perguruan tinggi juga dapat mempengaruhi pemahaman akuntansi seorang mahasiswa. Beberapa berpendapat bahwa tujuan utama pendidikan adalah untuk mempengaruhi perilaku individu dan bahwa pendidikan konservasi, di antara bidang-bidang lain, secara khusus menyerukan perubahan perilaku (Heimlich \& Ardoin, 2008). Perilaku belajar adalah suatu aktivitas belajar yang dilakukan suatu individu secara berulang-ulang agar menjadi suatu kebiasaan, sehingga individu tersebut dapat memahami hal yang tidak tahu menjadi tahu dan dari hal yang tidak bisa 
menjadi bisa. Sebuah kebiasaan atau perilaku belajar sangat berkaitan dengan penggunaan waktu yang baik untuk belajar ataupun untuk kegiatan lainnya.

Theory of planned behavior, perilaku belajar merupakan salah satu variabel yang dijelaskan oleh theory of planned behavior dari hubungan pada tiap-tiap variabel lainnya didalam penelitian ini. Perilaku belajar ini merupakan perilaku aktual dari sebelumnya sudah muncul adanya minat untuk berperilaku. Bila adanya sikap positif, dukungan dari orang sekitar, serta adanya persepsi kemudahan karena tidak ada hmbatan untuk berperilaku maka minat seseorang untuk berperilaku akan semakin tinggi. Teori atribusi menjelaskan bahwa perilaku belajar merupakan salah satu faktor internal dalam menentukan karakeristik seseorang, khususnya di penelitian ini tingkat pemahaman akuntansi pengantar seorang mahasiswa. Smith (2001) berpendapat bahwa belajar yang efisien dapat dicapai apabila menggunakan strategi yang tepat, yakni adanya pengaturan waktu yang baik dalam mengikuti perkuliahan, belajar di rumah, berkelompok, ataupun untuk mengikuti ujian.

Penelitian yang dilakukan Artana et al. (2014) menunjukan perilaku belajar berpengaruh positif secara signifikan terhadap tingkat pemahaman akuntansi. Hasil serupa ditemukan Putra (2018) bahwa perilaku belajar berpengaruh positif secara signifikan terhadap tingkat pemahaman akuntansi. Ogunyemi \& Hassan (2011), Crede \& Kuncel (2008), serta Hussain (2006) memberikan bukti bahwa kebiasaan belajar dan sikap belajar sama-sama signifikan terhadap kinerja akademik siswa.

Perilaku belajar yang baik akan mengarah pada pemahaman terhadap pelajaran yang maksimal. Jadi, jika prestasi akademik seorang mahasiswa baik, maka mahasiswa tersebut telah memperoleh hasil yang baik dari serangkaian proses belajar yang telah dilaluinya. Maka, dengan perilaku belajar yang baik akan mengarah pada pemahaman terhadap pelajaran yang maksimal. Sebaliknya, dampak dari perilaku belajar belajar yang buruk akan mengarah pada pemahaman terhadap pelajaran yang kurang maksimal. Berdasarkan uraian tersebut, dapat dirumuskan hipotesis sebagai berikut.

$\mathrm{H}_{2}$ : Perilaku belajar mahasiswa berpengaruh positif pada tingkat pemahaman akuntansi pengantar.

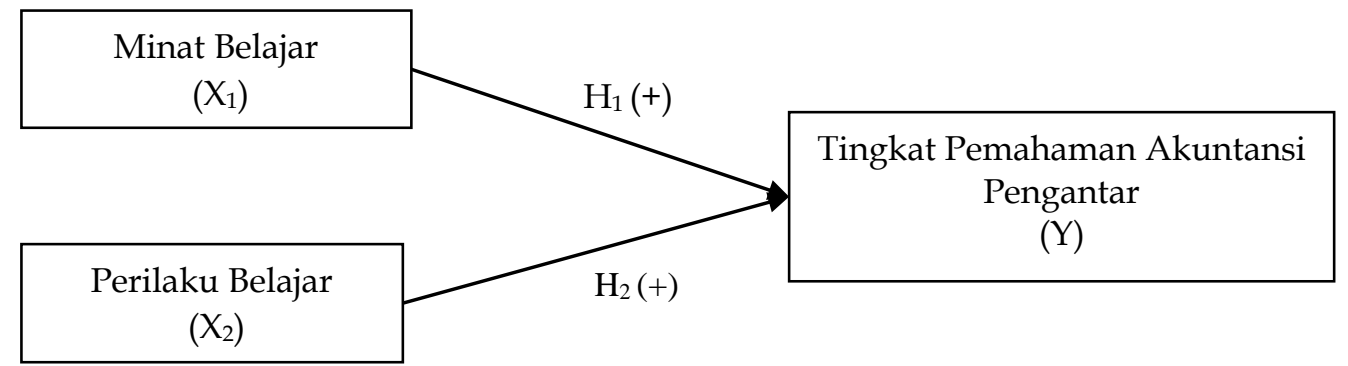

Sumber: Data Penelitian, 2019

Gambar 1. Desain Penelitian

\section{METODE PENELITIAN}

Pendekatan yang digunakan dalam penelitian ini adalah pendekatan kuantitatif berbentuk asosiatif. Pendekatan kuantitatif diartikan sebagai suatu metode penelitian yang digunakan untuk meneliti populasi atau sampel tertentu yang 
bertujuan untuk menguji hipotesis tertentu yang telah ditetapkan (Sugiyono, 2017: 55). Penelitian ini dilakukan pada di Fakultas Ekonomi dan Bisnis (FEB) Universitas Udayana. Obyek dalam penelitian ini adalah pengaruh minat dan perilaku belajar pada tingkat pemahaman akuntansi pengantar dan untuk mengetahui tingkat pemahaman akuntansi pengantar. Variabel dalam penelitian ini ada variabel independen yaitu minat belajar $\left(X_{1}\right)$ dan perilaku belajar $\left(X_{2}\right)$, serta variabel dependen yaitu tingkat pemahaman akuntansi pengantar (Y).

Populasi dalam penelitian ini adalah seluruh mahasiswa program studi S1 Akuntansi Fakultas Ekonomi dan Bisnis Universitas Udayana angkatan 2018 berjumlah 240 orang. Populasi ini dipilih dipilih karena mahasiswa angkatan 2018 tersebut masih baru berada diawal masa perkuliahan dan/atau baru melewati mata kuliah Pengantar Akuntansi I dan II, sehingga diharapkan telah memiliki gambaran mengenai manfaat maksimal dari proses belajar Pengantar Akuntansi. Teknik pengambilan sampel dalam penelitian ini adalah metode nonprobability sampling dengan teknik purposive sampling didapat sebanyak 200 responden. Kriteria yang digunakan untuk menentukan sampel dalam penelitian ini adalah mahasiswa akuntansi angkatan 2018 yang menjadi anggota atau masuk di dalam grup angkatan mahasiswa akuntansi angkatan 2018 Fakultas Ekonomi dan Bisnis Universitas Udayana. Kriteria ini ditentukan karena adanya keterbatasan waktu, biaya, dan tenaga peneliti, serta atas studi pendahuluan sebelumnya mahasiswa yang aktif dapat dilihat dari keikutsertaan mahasiswa dalam grup angkatan, maka sampel yang digunakan hanya berasal dari grup angkatan mahasiswa akuntansi angkatan 2018 Fakultas Ekonomi dan Bisnis Universitas Udayana.

Metode pengumpulan data adalah cara-cara yang dapat digunakan dalam penelitian ini adalah metode survei menggunakan media angket atau kuesioner. Mengukur hasil kuesioner berkaitan dengan variabel independen $(X)$ yang akan diteliti, digunakan skala likert poin 1 sampai 4 dengan menghilangkan pilihan netral atau ragu-ragu agar responden tidak cenderung memilih jawaban tersebut ketika menemukan pertanyaan yang meragukan. Sedangkan, untuk varibel dependen $(Y)$ dalam penelitian ini menggunakan skala guttman yaitu pilihan jawaban responden hanya "Benar" atau "Salah" terhadap suatu pernyataan yang diberikan. Jawaban dibuat dengan skor tertinggi satu dan terendah nol, kemudian total skor diukur menggunakan range score dalam satuan persentase. Konsisten dengan penelitian Chen \& Volpe (1998), adapun kriteria penentuan skor, yaitu Tingkat Pemahaman Tinggi (range $\geq 80 \%$ ) diberi skor 3, Tingkat Pemahaman Sedang (range $60 \%<$ skor < 80\%) diberi skor 2, dan Tingkat Pemahaman Rendah (range $\leq 60 \%$ ) diberi skor 1 .

Teknik analisis data dalam penelitian ini yaitu analisis regresi linear berganda untuk mengukur pengaruh antara lebih dari satu variabel bebas terhadap variabel terikat (Ghozali, 2016: 101). Teknik analisis ini digunakan untuk mengetahui pengaruh minat belajar dan perilaku belajar mahasiswa pada tingkat pemahaman akuntansi pengantar mahasiswa program studi S1 Akuntansi angkatan 2018 Fakultas Ekonomi dan Bisnis Universitas Udayana. 


\section{HASIL DAN PEMBAHASAN}

Pengumpulan data dilakukan melalui penyebaran kuesioner kepada 200 orang mahasiswa dengan studi pendahuluan sebelumnya. Penyebaran kuesioner hingga semua kuesioner terjawab dan terkumpul kembali pada penelitian ini menghabiskan waktu 7 hari.

\section{Tabel 1. Rincian Pengiriman dan Pengembalian Kuesioner}

\begin{tabular}{lc}
\hline Keterangan & Jumlah \\
\hline Kuesioner yang tersebar & 200 \\
Kuesioner yang tidak kembali & 50 \\
Kuesioner yang kembali & 150 \\
Tingkat Pengembalian (Respons rate) & $75 \%$ \\
Tingkat Pengembalian yang digunakan (useable response rate) & $100 \%$ \\
\hline
\end{tabular}

Sumber: Data Penelitian, 2019

Berdasarkan Tabel 1, dapat dijelaskan bahwa dari 200 kuesioner yang tersebar, sebanyak 150 kuesioner kembali dengan pengisian yang lengkap dan memenuhi ketentuan dan sisanya 50 kuesioner tidak kembali. Perhitungan dari data tersebut menghasilkan response rate $75 \%$ dengan useable response rate sebesar $100 \%$.

Hasil uji validitas menunjukkan bahwa seluruh instrumen penelitian yang digunakan untuk mengukur variabel minat belajar, perilaku belajar, dan tingkat pemahaman akuntansi pengantar memiliki nilai koefisien korelasi dengan skor total seluruh item pernyataan lebih besar dari 0,30 dengan signifikansi kurang dari 0,05. Hal ini menunjukkan bahwa butir-butir pernyataan dalam instrument penelitian tersebut valid dan layak digunakan sebagai instrument penelitian. Uji reliabilitas terhadap instrumen penelitian ini menggunakan nilai Cronbach's Alpha, yakni untuk mengetahui kevalidan butirbutir pernyataan terhadap variabel yang diteliti (minat belajar, perilaku belajar, dan tingkat pemahaman akuntansi pengantar). Rekapitulasi hasil uji reliabilitas instrumen penelitian dapat dilihat pada Tabel 2.

Tabel 2. Rekapitulasi Hasil Uji Reliabilitas Instrumen Penelitian

\begin{tabular}{llcc}
\hline No. & \multicolumn{1}{c}{ Variabel } & Cronbach's Alpha & Keterangan \\
\hline 1 & Minat Belajar $\left(\mathrm{X}_{1}\right)$ & 0,847 & Reliabel \\
2 & Perilaku Belajar $\left(\mathrm{X}_{2}\right)$ & 0,744 & Reliabel \\
3 & Tingkat Pemahaman Akuntansi & 0,761 & Reliabel \\
& Pengantar $(\mathrm{Y})$ & & \\
\hline
\end{tabular}

Sumber: Data Penelitian, 2019

Hasil uji reliabilitas yang disajikan dalam Tabel 2, menunjukkan bahwa seluruh instrumen penelitian memiliki koefisien Cronbach's Alpha lebih dari atau sama dengan 0,70. Jadi dapat dinyatakan bahwa seluruh variabel telah memenuhi syarat reliabilitas atau kehandalan sehingga dapat digunakan untuk melakukan penelitian. Sebelum dilakukan analisis regeresi linear berganda, harus lolos uji asumsi klasik yang disajikan dalam Tabel 3.

Berdasarkan hasil uji asumsi klasik pada uji normalitas bertujuan untuk menguji model regresi yang digunakan berdistribusi normal atau tidak. Diperoleh nilai signifikansi sebesar 0,513 seperti yang ditunjukkan oleh Tabel 3. Oleh karena nilai signifikansi uji Kolmogorov-Smirnov lebih dari 0,05 maka dapat disimpulkan bahwa model persamaan regresi tersebut berdistribusi normal. 
Tabel 3. Hasil Uji Asumsi Klasik

\begin{tabular}{|c|c|c|c|c|c|}
\hline \multirow{2}{*}{ Keterangan } & \multicolumn{2}{|c|}{$\begin{array}{c}\text { Uji } \\
\text { Normalitas }\end{array}$} & \multicolumn{2}{|c|}{$\begin{array}{c}\text { Uji } \\
\text { Multikolonieritas }\end{array}$} & \multirow{2}{*}{$\begin{array}{c}\text { Uji } \\
\text { Heteroskedastisitas } \\
\text { Sig. }\end{array}$} \\
\hline & $\begin{array}{l}\text { Kolmogorov- } \\
\text { Smirnov }\end{array}$ & Sig. & Tolerance & VIF & \\
\hline $\begin{array}{l}\text { Minat } \\
\text { Belajar }\left(X_{1}\right)\end{array}$ & \multirow[b]{2}{*}{0,819} & \multirow[b]{2}{*}{0,513} & 0,536 & 1,867 & 0,531 \\
\hline $\begin{array}{l}\text { Perilaku } \\
\text { Belajar }\left(\mathrm{X}_{2}\right)\end{array}$ & & & 0,536 & 1,867 & 0,401 \\
\hline
\end{tabular}

Sumber: Data Penelitian, 2019

Pada uji multikolonieritas bertujuan untuk menguji apakah dalam satu model regresi ditemukan adanya korelasi antar variabel bebas. Untuk mendeteksi ada atau tidaknya korelasi antar variabel bebas dapat dilihat dari nilai tolerance dan nilai variance inflation factor (VIF), jika nilai tolerance lebih dari $10 \%$ atau VIF kurang dari 10, maka dapat dikatakan model telah bebas dari multikoleniaritas. Diperoleh dalam Tabel 3, bahwa nilai tolerance variabel minat dan perilaku belajar 0,536 > 10\% dan nilai VIF 1,867 < 10 yang berarti model persamaan regresi bebas dari multikolonieritas.

Pada uji heteroskedastisitas ini bertujuan untuk mengetahui apakah dalam model regresi terjadi ketidaksamaan varians dari residual satu pengamatan ke pengamatan lain yang dilakukan dengan uji Glejser dan melihat nilai signifikansi berada diatas 0,05 maka model regresi bebas dari masalah heteroskedastisitas. Diperoleh dalam Tabel 3, dapat dilihat bahwa nilai signifikansi dari variabel minat belajar sebesar 0,531 >0,05, dan nilai signifikansi variabel perilaku sebesar 0,407 > 0,05 yang berarti tidak terjadi ketidaksamaan variance dari residual satu pengamatan ke pengamatan yang lain. Dengan demikian, model yang dibuat tidak mengandung gejala heteroskedastisitas.

Setelah semua asumsi klasik terpenuhi, maka selanjutnya memaparkan hasil analisis regresi linear berganda. Perhitungan koefisien regresi linier berganda dilakukan melalui software SPSS 20.0 for Windows yang ditunjukan pada Tabel 4.

Tabel 4. Hasil Analisis Regresi Linear Berganda

\begin{tabular}{|c|c|c|c|c|c|}
\hline \multirow[t]{2}{*}{ Model } & \multicolumn{2}{|c|}{$\begin{array}{c}\text { Unstandardized } \\
\text { Coefficients }\end{array}$} & \multirow{2}{*}{$\begin{array}{c}\begin{array}{c}\text { Standardized } \\
\text { Coefficients }\end{array} \\
\text { Beta }\end{array}$} & \multirow[t]{2}{*}{$\mathrm{T}$} & \multirow[t]{2}{*}{ Sig. } \\
\hline & B & Std. Error & & & \\
\hline (Constant) & 0,057 & 1,043 & & 0,055 & 0,957 \\
\hline Minat Belajar $\left(X_{1}\right)$ & 0,200 & 0,044 & 0,415 & 4,552 & 0,000 \\
\hline Perilaku Belajar $\left(X_{2}\right)$ & 0,112 & 0,047 & 0,219 & 2,400 & 0,018 \\
\hline Adjusted R Square & 0,335 & & & & \\
\hline F hitung & 38,609 & & & & \\
\hline Sig. F & 0,000 & & & & \\
\hline
\end{tabular}

Berdasarkan hasil analisis regresi linier berganda seperti yang disajikan pada Tabel 4, maka dapat dibuat persamaan regresi sebagai berikut.

$$
\mathrm{Y}=0,057+0,200 \mathrm{X}_{1}+0,112 \mathrm{X}_{2}
$$

Keterangan:

Y : Tingkat Pemahaman Akuntansi Pengantar

$\mathrm{X}_{1} \quad$ : Minat Belajar 


\section{$\mathrm{X}_{2} \quad$ : Perilaku Belajar}

Tabel 4, menunjukkan besarnya pengaruh variabel bebas terhadap variabel terikat yang ditunjukkan oleh nilai determinasi total (Adjusted $R$ Square) sebesar 0,335 mempunyai arti perubahan pada tingkat pemahaman akuntansi pengantar dapat dijelaskan oleh minat belajar dan perilaku belajar sebesar 33,5\%, sedangkan sisanya $66,5 \%$ dijelaskan oleh faktor lain yang tidak diuji dalam penelitian ini.

Hasil pengolahan data uji F (uji kelayakan model) dengan menggunakan

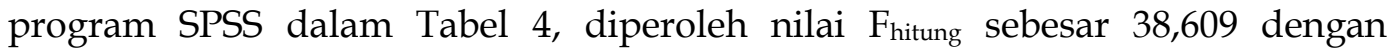
signifkansi sebesar 0,000 <0,05, maka dapat disimpulkan bahwa pada kelompok yang diuji memiliki perbedaan yang nyata (signifikan). Hasil ini mempunyai arti bahwa variabel minat belajar dan perilaku belajar berpengaruh secara bersamasama terhadap variabel tingkat pemahaman akuntansi pengantar.

Pengaruh variabel minat belajar dan perilaku belajar pada tingkat pemahaman akuntansi pengantar diuji dengan menggunakan Uji t (uji hipotesis). Kriteria pengujian untuk menjelaskan interpretasi pengaruh antar masingmasing variabel yakni apabila nilai signifikansi $<0,05$ maka $\mathrm{H}_{0}$ ditolak dan $\mathrm{H}_{1}$ diterima. Sebaliknya, jika nilai signifikansi $>0,05$ maka $\mathrm{H}_{0}$ diterima dan $\mathrm{H}_{1}$ ditolak.

Berdasarkan Tabel 4, hasil analisis pengaruh minat belajar mahasiswa pada tingkat pemahaman akuntansi pengantar diperoleh nilai koefisien regresi positif sebesar 0,200 memiliki arti apabila minat belajar meningkat sebesar 1 satuan maka tingkat pemahaman akuntansi pengantar $(\mathrm{Y})$ juga akan semakin meningkat sebesar 0,200 dengan asumsi variabel lainnya konstan. Nilai Signifikansi sebesar 0,000 0,05 mengindikasikan bahwa $\mathrm{H}_{0}$ ditolak dan $\mathrm{H}_{1}$ diterima. Hasil ini mempunyai arti bahwa bahwa minat belajar mahasiswa $\left(\mathrm{X}_{1}\right)$ berpengaruh positif dan signifikan pada tingkat pemahaman akuntansi pengantar $(\mathrm{Y})$. Hal ini menunjukkan bahwa semakin tinggi minat belajar yang dimiliki mahasiswa maka meningkatkan tingkat pemahaman akuntansi pengantar mahasiswa tersebut.

Minat individu telah digambarkan sebagai kecenderungan yang relatif abadi untuk hadir pada objek dan peristiwa tertentu dan untuk terlibat dalam kegiatan tertentu (Ainley et al., 2002). Minat besar pengaruhnya terhadap belajar, karena bila bahan pelajaran tidak sesuai dengan minat mahasiswa, mahasiswa tidak akan belajar dengan sebaik-baiknya, karena tidak ada daya tarik baginya. Pada penelitian Ishak (2011) menyatakan minat belajar yang tinggi akan dapat terwujud apabila mahasiswa sadar akan tanggung jawab sebagai mahasiswa, sehingga mampu meningkatkan motivasi dan disiplin diri agar mampu mencapai target yang diinginkan dalam memahami suatu materi terlebih lagi akuntansi. Hasil penelitian ini sejalan dengan beberapa penelitian sebelumnya, yaitu Dian (2015), Atmaja et al. (2017), Sugiartini et al. (2017), dan Putra (2018) menyatakan dalam penelitiannya bahwa minat belajar berpengaruh positif terhadap tingkat pemahaman akuntansi.

Pada theory of planned behavior, minat belajar merupakan salah satu variabel yang dijelaskan oleh theory of planned behavior dari hubungan pada tiaptiap variabel lainnya didalam penelitian ini. Minat yang muncul ini disebabkan karena tiga faktor yaitu sikap dari mahasiswa yang yakin atas hasil dari perilaku 
mahasiswa itu sendiri, norma/aturan yang mampu memotivasi mahasiswa, dan pengendalian yang mampu mendukung atau menghambat perilakunya dalam membuat tingkat pemahaman akuntansi pengantar seorang mahasiswa dapat menjadi lebih tinggi. Suatu minat dapat diekspresikan melalui suatu pernyataan yang menunjukan bahwa mahasiswa lebih menyukai suatu hal dari pada yang lainnya dapat pula dimanifestasikan melalui partisipasi dalam bentuk aktivitas. Pada teori atribusi, minat belajar merupakan salah satu faktor internal dalam menentukan karakeristik seseorang. Hal ini berarti semakin tinggi minat belajar mahasiswa maka semakin tinggi tingkat pemahamannya.

Berdasarkan Tabel 4, hasil analisis pengaruh perilaku belajar mahasiswa pada tingkat pemahaman akuntansi pengantar diperoleh nilai koefisien regresi positif sebesar 0,112 memiliki arti apabila perilaku belajar (X2) meningkat sebesar 1 satuan maka tingkat pemahaman akuntansi pengantar $(Y)$ juga akan semakin meningkat sebesar 0,112 dengan asumsi variabel lainnya konstan. Nilai signifikansi sebesar 0,018 < 0,05 mengindikasikan bahwa $\mathrm{H}_{0}$ ditolak dan $\mathrm{H}_{2}$ diterima. Hasil ini mempunyai arti bahwa bahwa perilaku belajar mahasiswa $\left(\mathrm{X}_{2}\right)$ berpengaruh positif dan signifikan pada tingkat pemahaman akuntansi pengantar $(\mathrm{Y})$. Hal ini menunjukkan bahwa semakin tinggi perilaku belajar yang dimiliki mahasiswa maka meningkatkan tingkat pemahaman akuntansi pengantar mahasiswa tersebut.

Perilaku pembelajaran dapat menjadi salah satu alasan yang mempengaruhi tingkat pemahaman mahasiswa terhadap akuntansi pengantar. Seperti yang dinyatakan oleh Suprianto \& Harryoga (2015) suatu perilaku pembelajaran yang baik akan dapat membantu meningkatkan kemampuan mahasiswa dalam mengatasi masalah belajarnya sehingga mahasiswa dapat memperoleh tingkat pemahaman akuntansi yang baik. Perilaku belajar yang baik akan mengarah pada pemahaman terhadap pelajaran yang maksimal. Jadi, jika prestasi akademik seorang mahasiswa baik, maka mahasiswa tersebut telah memperoleh hasil yang baik dari serangkaian proses belajar yang telah dilaluinya. Hasil penelitian ini sejalan dengan beberapa penelitian sebelumnya, yaitu Artana et al. (2014), Rusmiani \& Widanaputra (2017), dan Putra (2018) menyatakan bahwa perilaku belajar mahasiswa berpengaruh positif secara signifikan terhadap tingkat pemahaman akuntansi. Pada penelitian Hussain (2006), Crede \& Kuncel (2008), dan Ogunyemi \& Hassan (2011) juga menyatakan dalam penelitiannya bahwa kebiasaan belajar dan sikap belajar sama-sama signifikan terhadap akademik siswa.

Pada theory of planned behavior, perilaku belajar merupakan salah satu variabel yang dijelaskan oleh theory of planned behavior dari hubungan pada tiaptiap variabel lainnya didalam penelitian ini. Perilaku belajar ini merupakan perilaku aktual dari sebelumnya sudah muncul adanya minat untuk berperilaku. Bila adanya sikap positif, dukungan dari orang sekitar, serta adanya persepsi kemudahan karena tidak ada hambatan untuk berperilaku maka minat seseorang untuk berperilaku akan semakin tinggi. Pada teori atribusi, perilaku belajar merupakan salah satu faktor internal dalam menentukan karakeristik seseorang. Hal ini berarti semakin baik perilaku belajar mahasiswa maka semakin tinggi tingkat pemahamannya. 


\section{SIMPULAN}

Berdasarkan hasil analisis data dan pembahasan yang telah diuraikan, maka dapat ditarik kesimpulan, yaitu minat belajar berpengaruh positif pada tingkat pemahaman akuntansi pengantar. Hal ini berarti bahwa semakin tinggi minat belajar, maka tingkat pemahaman akuntansi pengantar semakin tinggi, serta perilaku belajar berpengaruh positif pada tingkat pemahaman akuntansi pengantar. Hal ini berarti bahwa semakin baik perilaku belajar, maka tingkat pemahaman akuntansi pengantar semakin tinggi.

Saran yang dapat diberikan berdasarkan hasil penelitian adalah sebagai berikut: 1) Bagi Perguruan tinggi diharapkan memberikan fasilitas yang cukup dalam proses kegiatan belajar mengajar, baik dalam sistem pembelajaran di kelas ataupun dengan fasilitas yang disediakan; 2) Bagi mahasiswa disarankan untuk melakukan pembelajaran secara berulang-ulang, meningkatkan kebiasaan membaca buku, dan memperbaiki kebiasaan dalam mengikuti pelajaran, agar setelah lulus dari perguruan tinggi memiliki dasar ilmu yang cukup sehingga mampu mempraktikan ilmu di dunia kerja. 3) Bagi peneliti selanjutnya, agar dapat meneliti dan mengkaji lebih dalam faktor-faktor lain yang tidak diteliti dalam penelitian ini karena hasil koefisien determinasi sebesar 33,5\% sedangkan sisanya sebesar $66,5 \%$ dipengaruhi oleh faktor lain, seperti faktor lingkungan eksternal dan faktor.

\section{REFERENSI}

Abrantes, J. L., Seabra, C., \& Lages, L. F. (2007). Pedagogical Affect, Student Interest, and Learning Performance. Journal of Business Research, 60(9), 960-964. https:// doi.org/10.1016/j.jbusres.2006.10.026

Ainley, M., Hidi, S., \& Berndorff, D. (2002). Interest, Learning, and The Psychological Processes That Mediate Their Relationship. Journal of Educational Psychology, 94(3), 545-561. https://doi.org/10.1037/00220663.94.3.545

Aldito, B. (2018). Pemahaman Mahasiswa Tingkat Awal Terhadap Mata Kuliah Akuntansi Pengantar: Analisis Berbasis Asal Sekolah Menengah dan Gender. Universitas Islam Indonesia. Retrieved from https://dspace.uii.ac.id/handle/123456789/12268

Artana, M. B., Herawati, N. T., \& Atmadja, A. W. T. (2014). Pengaruh Kecerdasan Intelektual (IQ), Kecerdasan Emosional (EQ), Kecerdasan Spiritual (SQ), dan Perilaku Belajar Terhadap Pemahaman Akuntansi (Studi Kasus Pada Mahasiswa S1 Akuntansi Universitas Pendidikan Ganesha Singaraja dan Mahasiswa S1 Universitas Ud. E-Journal S1 Ak Universitas Pendidikan Ganesha, 2(1). Retrieved from https:// ejournal.undiksha.ac.id/index.php/S1ak/article/view/4396

Atmaja, R., Ramantha, I. W., \& Suartana, I. W. (2017). Pengaruh Minat Belajar Pada Pemahaman Akuntansi dengan Kecerdasan Emosional dan Kecerdasan Spiritual Sebagai Pemoderasi. E-Jurnal Ekonomi Dan Bisnis Universitas Udayana, 6(5), 2021-2046. Retrieved from https://ojs.unud.ac.id/index.php/EEB/article/view/29302 
Baker, R. E., Simon, J. R., \& Bazeli, F. P. (1987). Selecting Instructional Design for Introductory Accounting Based on The Experiential Learning Model. Journal of Accounting Education, 5(2), 207-226. https:/ / doi.org/10.1016/0748-5751(87)90019-4

Bakhri, S. (2011). Pengaruh Latar Belakang Pendidikan Mahasiswa Akuntansi Terhadap Pemahaman Mata Kuliah Pengantar Akuntansi. Universitas Islam Negeri Sultan Syarif Kasim Riau. Retrieved from http://repository.uinsuska.ac.id/9980/

Boyd, D. T., Boyd, S. C., \& Boyd, W. L. (2010). Changes in Accounting Education: Improving Principles Content for Better Understanding. Journal of Education for Business, 76(1), 36-42. https:// doi.org/10.1080/08832320009599048

Chen, H., \& Volpe, R. P. (1998). An Analysis of Personal Financial Literacy Among College Students. Financial Services Review, 7(2), 107-128.

Crede, M., \& Kuncel, N. (2008). Study Habits Meta-Analysis. Perspectives on Psychological Science In Press, 3(6), 425-453. Retrieved from www.psychologicalscience.org/journals/pps/3_6_inpress/crede.pdf

Dian. (2015). Pengaruh Kecerdasan Emosional Dan Minat Belajar Terhadap Tingkat Pemahaman Akuntansi (Studi Pada Mahasiswa Jurusan Akuntansi STIESIA Surabaya). STIESIA Surabaya.

Diller-Haas, A. (2004). Time to change introductory accounting.pdf. The CPA Journal, 74(4), 60-62. Retrieved from https:/ / search.proquest.com/docview /212297803?accountid=32506

Elias, R. Z. (2010). Students ' Approaches to Study in Introductory Accounting Courses. Journal of Education for Business, 80(4), 194-199. https:// doi.org/10.3200/JOEB.80.4.194-199

Ghozali, I. (2016). Aplikasi Analisis Multivariete Dengan Program IBM SPSS 23 (8th ed.). Semarang: Badan Penerbit Universitas Diponegoro.

Heimlich, J. E., \& Ardoin, N. M. (2008). Understanding Behavior to Understand Behavior Change: A Literature Review. Environmental Education Research, 14(3), 215-237. https:/ / doi.org/10.1080/13504620802148881

Hussain, A. (2006). Effect of Guidance Services on Study Attitudes, Study Habits and Academic Achievement of Secondary School Students. Bulletin of Education and Research, 28(1), 35-45.

Ishak, P. (2011). Pengaruh Kecerdasan Emosional, Kecerdasan Spiritual, dan Minat Belajar Terhadap Pemahaman Akuntansi (Studi Pada Mahasiswa Akuntansi Universitas Brawijaya Malang Angkatan 2010). Jurnal Ilmiah Mahasiswa FEB, 2(2). Retrieved from https://jimfeb.ub.ac.id/index.php/jimfeb/article/view/1289

Kahu, E., Nelson, K., \& Picton, C. (2017). Student Interest as a Key Driver of Engagement for First Year Students. Student Success, 8(2), 55. https:// doi.org/10.5204/ssj.v8i2.379

Lee, Y., Chao, C., \& Chen, C. (2011). The Influences of Interest in Learning and Learning Hours on Learning Outcomes of Vocational College Students in Taiwan: Using a Teacher's Instructional Attitude as The Moderator. Global Journal of Engineering Education, 13(3), 140-153. Retrieved from 
http://www.wiete.com.au/journals/GJEE/Publish/vol13no3/01-LeeY-J.pdf

Ogunyemi, A., \& Hassan, E. (2011). Academic Self-Efficacy, Study Habit and Attitude in School-Based Assessment. African Journal for the Study of Educational, 4. Retrieved from http://ajeduionline.org/3-6.php

Plant, E. A., Ericsson, K. A., Hill, L., \& Asberg, K. (2005). Why Study Time does not Predict Grade Point Average Across College Students: Implications of Deliberate Practice for Academic Performance. Contemporary Educational Psychology, 30, 96-116.

Putra, H. Y. W. (2018). Pengaruh Kecerdasan Emosional, Perilaku Belajar dan Minat Belajar Terhadap Tingkat Pemahaman Akuntansi (Studi pada Mahasiswa Fakultas Ekonomi dan Bisnis Jurusan Akuntansi Universitas Jember). Universitas Jember. Retrieved from https:// repository.unej.ac.id/handle/123456789/90612

Rusmiani, N. K. A., \& Widanaputra, A. A. G. P. (2017). Pengaruh Kecerdasan Emosional, Kecerdasan Intelektual, dan Perilaku Belajar Pada Tingkat Pemahaman Akuntansi. E-Jurnal Akuntansi Universitas Udayana, 20(2), 959-985. https:// doi.org/https://doi.org/10.24843/EJA.2017.v20.i02.p04

Sari, M. M. R., Suputra, I. D. G. D., \& Supadmi, N. L. (2017). Pemahaman Akuntansi, Profesionalisme, dan Kinerja Pemeriksa Pajak Pada KPP Pratama Se-Bali. Jurnal Ilmiah Akuntansi Dan Bisnis, 12(1), 36-43.

Smith, P. (2001). Understanding Self - Regulated Learning and its Impications for Accounting Educators and Research. Issues in Accounting Education, 16(4), 663-701.

Sugiartini, P. E., Herawati, N. T., \& Sulindawati, L. G. (2017). Pengaruh Kecerdasan Emosional dan Minat Belajar Terhadap Tingkat Pemahaman Akuntansi dengan Kepercayaan Diri Sebagai Variabel Pemoderasi (Studi Kasus Pada Mahasiswa S1 Akuntansi Universitas Pendidikan Ganesha). E-Journal S1 Ak Universitas Pendidikan Ganesha, 7(1). Retrieved from https://ejournal.undiksha.ac.id/index.php/S1ak/article/download/10 $134 / 6458$

Sugiyono. (2017). Metode Penelitian Bisnis Pendekatan Kuantitatif, Kualitatif, Kombinasi, dan $R \mathcal{E} D$ (3rd ed.). Bandung: Alfabeta.

Suprianto, E., \& Harryoga, S. (2015). Faktor-Faktor Penentu Tingkat Pemahaman. Jurnal Ekonomi Dan Bisni, XVIII(3), 75-90.

Syah, M. I. (2010). Analisis Pemahaman Mahasiswa Akuntansi dalam Menghadapi Mata Kuliah Dasar - Dasar Akuntansi (Studi Pada Mahasiswa Akuntansi S1 Universitas Inlam Negeri Sultan Syarif Kasim Riau). Universitas Islam Negeri Sultan Syarif Kasim Riau. Retrieved from http:// repository.uinsuska.ac.id/id/eprint/10694

Weygandt, J. J., Lorena, M., Michaela, R., Keryn, C., Kieso, D. E., \& Kimmel, P. D. (2013). Principles of Financial Accounting (3rd ed.). Australia: John Wiley and Sons Australia, Ltd. 
Yu, D. D. (2011). How Much Do Study Habits, Skills, and Attitudes Affect Student Performance in Introductory College Accounting Courses?. New Horizon in Edication, 59(3), 1-15. 